\title{
Solvent enhanced ion chromatography of alkaline earth and transition metal ions on porous monolithic silica
}

\author{
Edel Sugrue $^{\text {a }}$, Pavel N. Nesterenko ${ }^{\mathrm{b}}$, Brett Paull ${ }^{\mathrm{a}, *}$ \\ a National Centre for Sensor Research, School of Chemical Sciences, Dublin City University, Glasnevin, Dublin 9, Ireland \\ ${ }^{\mathrm{b}}$ Department of Analytical Chemistry, Lomonosov Moscow State University, Moscow 119899, Russian Federation
}

Received 4 May 2005; received in revised form 26 July 2005; accepted 29 July 2005

Available online 6 September 2005

\begin{abstract}
The high-performance separation of alkaline earth and transition metal ions on a bare porous silica $10.0 \mathrm{~cm} \times 0.46 \mathrm{~cm}$ monolith $($ Merck Chromolith $\mathrm{Si}$ ) was achieved using solvent enhanced ion chromatography. Using acetonitrile or methanol based ammonium and sodium acetate buffered mobile phases, the effect upon cation retention of mobile phase ionic strength, organic content and $\mathrm{pH}$ were evaluated. Increasing mobile phase acetonitrile concentration from 60 to $80 \%$ acetonitrile resulted in 10-15-fold increases in cation retention due to reduced hydration of the metal ions and hence enhanced ion-exchange interactions with surface silanol groups. The optimised conditions for the separation of $\mathrm{Cu}(\mathrm{II}), \mathrm{Cd}(\mathrm{II}), \mathrm{Ni}(\mathrm{II}), \mathrm{Co}(\mathrm{II})$ and $\mathrm{Mn}$ (II) were found to be $80 \% \mathrm{MeCN}$ with $10.3 \mathrm{mM}$ ammonium acetate (pH 4.6). Detection of transition metal ions was obtained using post-column reaction with 4-(2-pyridylazo) resorcinol and absorbance at $510 \mathrm{~nm}$. Under elevated flow conditions (up to $5 \mathrm{~mL} / \mathrm{min}$ ), total runs times could be reduced to under $4 \mathrm{~min}$. Optimum peak efficiencies were seen at flow rates of between 1.5 and $2 \mathrm{~mL} / \mathrm{min}$ and were equivalent to an average efficiency of $25,000 \mathrm{~N} / \mathrm{m}$.
\end{abstract}

(C) 2005 Elsevier B.V. All rights reserved.

Keywords: Monolithic silica; Alkaline earth metal ions; Transition metal ions; Solvent enhanced ion chromatography

\section{Introduction}

Since the first paper describing the application of porous silica rods for HPLC was published by Tanaka and co-workers [1], scientists have been motivated to study their performance and possible application [2]. The unique properties of monoliths, in particular their tolerance to high flow rates whilst maintaining excellent peak efficiencies, and the rapid speed of chromatographic separations that can be achieved at acceptable backpressures, make the monolithic column format more suitable to some applications than commonly used micro-particulate packed columns. However, due to the fact that monolith column technology is still relatively new, the number of different stationary phase chemistries and separation modes remains much smaller than that available for packed columns. In particular, both polymer and

\footnotetext{
* Corresponding author. Tel.: +353 1 7005060; fax: +353 17005503 .

E-mail address: Brett.Paull@dcu.ie (B. Paull).
}

silica based monolithic columns have overwhelmingly been applied to reversed-phase separations only, and have received less attention in other modes of LC, including ion exchange and ion chromatography (IC). However, a limited number of research groups have recently been exploring the potential use of monolithic phases for rapid high-performance separations of smaller ionic species with some considerable success, including application to separations of inorganic anions and inorganic cations [3-12]. The majority of these early studies have used liquid ion-exchangers dynamically coated onto reversed-phase monoliths [3-5,7,10], although a few papers have now appeared describing covalently bonded ion-exchangers based upon monolithic supports $[6,11,12]$ and even agglomerated porous monolithic substrates $[8,9]$. An early review of all of the above work, describing new possibilities in ion analysis using monolithic columns has recently been compiled [13].

In a recent study, Pack and Risley described the use of a bare silica porous monolith to separate a number of alkali 
metal cations using an ammonium acetate buffer mobile phase containing up to $90 \%$ acetonitrile. Detection was achieved using evaporative light scattering detection (ELSD) and the technique was applied to the determination of alkali metal counter ions in a number of pharmaceutical preparations [14]. The authors described the separation as being based upon hydrophilic interaction chromatography (HILIC). The term hydrophilic interaction chromatography has been assigned to LC that is based upon the use of polar stationary phases with less polar mobile phases. Usually, the HILIC mobile phase contains a high percentage of an organic solvent, typically $60-90 \%$ acetonitrile and a $10-40 \%$ water or aqueous buffer. Under these conditions the role of weak interactions like dipole-dipole, ion-dipole and hydrogen bonding between the analyte and stationary phase is remarkably enhanced and results in stronger retention of polar solutes. Theory of HILIC also states that retention can be governed through the partition of polar analytes into an enriched stagnant water layer on the stationary phase surface. Through increasing the organic content of the mobile phase, this partition coefficient is increased for polar solutes, resulting in increased retention [14]. The retention behaviour seen with HILIC is the opposite to that of reversed-phase liquid chromatography and similar to normal phase selectivity, although the high water content of the mobile phase means improved solubility for polar analytes. To-date HILIC has seen most application to small charged biomolecules.

In the case of the separation of small ions on polar stationary phases, as in the experiments described by Pack and Risley using porous monolithic silica [14], the above explanation of retention behaviour may not be entirely suitable. Pack and Risley showed that retention of the alkali cations was dependent upon \% organic solvent, ionic strength and mobile phase $\mathrm{pH}$. The effect of increasing ionic strength of the mobile phase was to decrease retention, clearly due to weak ion-exchange interactions with the surface silanol groups. In addition, an increase in mobile phase $\mathrm{pH}$, over the range 3.5-6.5, saw a subsequent increase in retention, presumably again due to the dissociation of surface silanol groups. This was the basis of the assumption that the retention mechanism was based upon HILIC.

However, retention of alkali and alkaline earth metal ions on bare silica supports has been shown in many previous studies [15-21]. In these cases, weak ion-exchange interactions were responsible for ion retention. Under conditions of high concentrations of organic solvent within the mobile phase such interactions will become stronger due to a reduced number of waters of hydration associated with the ion. This effect is commonly seen within inorganic ion exchange [18,19,22]. In cation exchange, increasing mobile phase organic solvent content has been shown to cause significant changes. The exact effect depends on the dielectric constant of organic solvent and its ability to form hydrogen bonds. For example, the increase of alcohol content in the mobile phase has actually been shown to cause a decrease in retention times of alkali and alkaline metal cations on silica, due to interac- tions with silanols groups and a corresponding decrease in its ion-exchange capacity [20]. Alternatively, an increase of acetonitrile content in water based mobile phases has been shown to produce the opposite effect of increasing retention $[18,19]$. With this in mind, it is therefore proposed here that what was actually observed by Pack and Risley [14] was in fact solvent enhanced ion-exchange interactions and, correspondingly the separation mode is solvent enhanced ion chromatography (SEIC) rather than HILIC.

In the work presented here, the solvent affect described by Pack and Risley [14] is investigated further through application to alkaline earth and transition/heavy metal cations. The ability to efficiently and rapidly separate the full suite of common transition and heavy metal cations is still a challenging task and the ability to utilise simple silica monoliths for this purpose has clear advantages [23].

\section{Experimental}

\subsection{Chromatographic conditions}

A Dionex Model GPM2 Gradient Pump Module (Sunnyvale, CA, U.S.A.) was used to deliver the eluent (1.0-4.0 $\mathrm{mL} / \mathrm{min})$. An automated injection value, fitted with a $20 \mu \mathrm{L}$ injection loop was used for the introduction of standards. A PEEK lined bare silica monolithic column (Performance SI) of $10 \mathrm{~cm}$ in length and $4.6 \mathrm{~mm}$ i.d. was purchased from Merck KGaA (Damstadt, Germany). According to the manufacturer the silica monolith had a surface area of $300 \mathrm{~m}^{2} \mathrm{~g}^{-1}$, with a $2 \mu \mathrm{m}$ macroporous and $13 \mathrm{~nm}$ mesoporous structure. A pressure driven Dionex Reagent Delivery Module was used for the introduction of the PCR, which was mixed at room temperature with the eluent using a $0.5 \mathrm{~m}$ PEEK reaction coil, $0.25 \mathrm{~mm}$ i.d. (the $0.5 \mathrm{~m}$ reaction coil was required to ensure adequate mixing of the eluent and PCR at elevated flow rates). An applied Biosystems 400 Solvent Delivery System (Foster City, CA, U.S.A.) was used to deliver the PCR when eluent flow rates greater than $3 \mathrm{~mL} / \mathrm{min}$ were employed. A 1050 series, Hewlett-Packard UV-vis detector (Palo Alto, CA, U.S.A.) was used to monitor the resultant chromatograms. When working with eluent flow rates $>3.5 \mathrm{~mL} / \mathrm{min}$, a Waters Model 600E Multisolvent Delivery System (Waters, Milford, MA, U.S.A.) was used as the eluent delivery system, and a Schimadzu Model SPD-6AV UV-vis detector (Kyoto, Japan) was used to monitor the resultant chromatograms. Data acquisition was at a rate of $10 \mathrm{~Hz}$ with processing of chromatograms performed using a PeakNet 6.0 chromatography workstation (Dionex).

\subsection{Reagents}

Acetonitrile, methanol (HPLC grade, LabScan Ltd., Stillorgan Ind. Park, Dublin), ammonium acetate, sodium acetate (Aldrich Chemicals Ltd., Gillingham, UK) and glacial acetic acid (Merck KGaA) were used to prepare the required 
eluents. All eluents and standard solutions were prepared using deionised water from a Millipore Milli-Q water purification system (Bedford, MA, U.S.A.), and were filtered through a $0.45 \mu \mathrm{m}$ filter and degassed by sonication. The PCR reagent used for the detection of transition metals consisted of a mixture of $0.4 \mathrm{mM}$ 4-(2-pyridylazo) resorcinol (PAR, purchased form Sigma-Aldrich, Gillingham, UK) and 0.5 M ammonia (BDH Laboratory Supplies, Poole, England), adjusted to $\mathrm{pH} 10.5$ (monitored at $510 \mathrm{~nm}$ ). For the detection of alkaline earth metals the PCR reagent used was $0.4 \mathrm{mM} o$-cresolphthalein complexone (o-CPC, Sigma-Aldrich), $0.25 \mathrm{M}$ boric acid (Sigma-Aldrich, Tallaght, Dublin, Ireland) adjusted to $\mathrm{pH} 10.5$ with $1 \mathrm{M} \mathrm{NaOH}$ (monitored at $570 \mathrm{~nm}$ ). Low-level standard solutions of metal cations were generally made up freshly each day from stock solutions (1000 ppm). $\mathrm{Mg}$ (II), $\mathrm{Ca}$ (II), $\mathrm{Sr}$ (II), $\mathrm{Ba}$ (II), $\mathrm{Mn}$ (II), $\mathrm{Co}(\mathrm{II}), \mathrm{Ni}(\mathrm{II}), \mathrm{Cd}(\mathrm{II}), \mathrm{Zn}(\mathrm{II})$ and $\mathrm{Pb}(\mathrm{II})$ standards were prepared from their chloride salts (Sigma-Aldrich) and Fe(II) and $\mathrm{Cu}(\mathrm{II})$ standards were prepared from their sulphate salts (Sigma-Aldrich).

\section{Results and discussion}

\subsection{Alkaline earth metals—organic solvent and buffer effects}

Initial experiments were performed to extend the work of Pack and Risley to include alkaline earth metal ions [14]. Therefore, using an acetic acid/ammonium acetate buffer within an acetonitrile based mobile phase, the effect upon selectivity of varying the buffer concentration within mobile phases of varying $\%$ acetonitrile was investigated. The acetonitrile was varied from 60 to $80 \%(n=3)$, whilst the ammonium acetate buffer concentration was varied from 10.5 to $42.1 \mathrm{mM}(n=4), 7.8$ to $31.3 \mathrm{mM}(n=4), 5.2$ to $20.6 \mathrm{mM}$ $(n=4)$, for 60,70 and $80 \%$ acetonitrile, respectively. For each mobile phase prepared, the $\mathrm{pH}$ was constant at 4.6. Table 1 show the retention data obtained, together with the slope and correlation coefficient data for the dependences of $\log k$ from the $\log$ of the buffer concentration, $[E]$. As can be seen from Table 1, a linear relationship between $\log [E]$ and retention was evident with each \% of $\mathrm{MeCN}$, and in general the slopes for all four alkaline earth metals did not vary significantly, and so no noteworthy selectivity changes were seen.

The data shown in Table 1 show considerable increases in retention for all four cations with increasing mobile phase $\%$ $\mathrm{MeCN}$. Ten to 15 -fold increases in retention factors $(k)$ can be seen with an increase in $\% \mathrm{MeCN}$ from 60 to $80 \%$. A number of studies have investigated the effect upon ion exchange of increasing the organic character of the mobile phase on inorganic ion-exchangers $[14,18-20,24]$. These studies conclude that the degree of hydration of the analyte and eluent ions has a major influence upon selectivity, and that by including organic solvents within the mobile phase, both ions in solution and fixed ion-exchange sites within the stationary
Table 1

Retention data for alkaline earth metal ions on a $10 \mathrm{~cm}$ bare silica monolithic column using an acetonitrile mobile phase containing ammonium acetate buffer-( $\mathrm{pH} 4.6)$

\begin{tabular}{lrrrr}
\hline $\log [E]$ & \multicolumn{1}{l}{$\log k$} & & & \\
\cline { 2 - 5 } & $\mathrm{Ca}(\mathrm{II})$ & $\mathrm{Mg}(\mathrm{II})$ & $\mathrm{Sr}(\mathrm{II})$ & $\mathrm{Ba}(\mathrm{II})$ \\
\hline $60 \% \mathrm{MeCN}$ & & & & \\
-1.98 & 0.324 & 0.283 & 0.324 & 0.436 \\
-1.68 & 0.057 & 0.053 & 0.068 & 0.182 \\
-1.50 & 0.000 & -0.013 & 0.049 & 0.161 \\
-1.38 & -0.260 & -0.284 & -0.210 & -0.208 \\
Slope & -0.853 & -0.884 & -0.790 & -0.930 \\
$R^{2}$ & 0.913 & 0.932 & 0.903 & 0.842 \\
$70 \%$ MeCN & & & & \\
-2.11 & 0.728 & 0.683 & 0.821 & 0.914 \\
-1.81 & 0.430 & 0.418 & 0.509 & 0.635 \\
-1.63 & 0.260 & 0.223 & 0.328 & 0.449 \\
-1.51 & 0.170 & 0.170 & 0.289 & 0.418 \\
Slope & -0.937 & -0.884 & -0.920 & -0.862 \\
$R^{2}$ & 0.997 & 0.989 & 0.981 & 0.979 \\
$80 \%$ MeCN & & & & \\
-2.28 & 1.417 & 1.450 & & \\
-1.99 & 0.969 & 0.985 & & \\
-1.81 & 0.849 & 0.879 & & \\
-1.69 & 0.694 & 0.704 & & \\
Slope & -1.186 & -1.211 & & \\
$R^{2}$ & 0.979 & 0.975 & & \\
\hline
\end{tabular}

Flow rate $=1 \mathrm{~mL} / \mathrm{min}$, column temperature $=20^{\circ} \mathrm{C}$ and post-column reaction detection with $o-\mathrm{CPC}$ monitored at $570 \mathrm{~nm}$.

phase will lose waters of hydration. In addition, selectivity will also be much affected by the extent of hydrogen bonding of the solvent molecules with surface silanol groups. In most cases, reduced hydration results in enhanced analyte ion interaction with the stationary phase exchange sites and thus increased retention. The exact nature of this effect would depend upon the relative solvation of the analyte and eluent ions and the nature of the organic solvent, namely its dielectric constant. Solvents that exhibit strong hydrogen bonding properties should result in a relatively smaller retention increase or even decrease compared to solvents that do not exhibit such properties.

At 60 and $70 \% \mathrm{MeCN}$, the retention order shown with the $\mathrm{MeCN}$ mobile phase was typical of that seen with ionexchange, namely $\mathrm{Mg}$ (II) $<\mathrm{Ca}$ (II) $<\mathrm{Sr}$ (II) $<\mathrm{Ba}$ (II). However, at $80 \% \mathrm{MeCN} \mathrm{Mg}(\mathrm{II})$ was retained for slightly longer than $\mathrm{Ca}(\mathrm{II})$. Apart from the above change in retention order, the mobile phase $\mathrm{MeCN}$ concentration also had relatively little effect upon individual cation selectivity, with relative retention of all metals increasing at a roughly equal rate.

Fig. 1(a) shows the overlay of three chromatograms of $\mathrm{Mg}(\mathrm{II}), \mathrm{Sr}(\mathrm{II})$ and $\mathrm{Ba}(\mathrm{II})$ standards obtained with a $70 \%$ MeCN mobile phase at an acetate buffer concentration of $31.3 \mathrm{mM}(\mathrm{pH} 4.6)$, delivered at a flow rate of $1 \mathrm{~mL} / \mathrm{min}$. Clearly, although peak shapes for $\mathrm{Mg}$ (II) and $\mathrm{Ba}$ (II) are good, $\mathrm{Ca}(\mathrm{II})$ and $\mathrm{Sr}(\mathrm{II})$ exhibited peak splitting, and under the conditions shown $\mathrm{Ca}$ (II) co-eluted with $\mathrm{Mg}$ (II). The close selectivity exhibited for $\mathrm{Ca}(\mathrm{II})$ and $\mathrm{Mg}(\mathrm{II})$ under different 

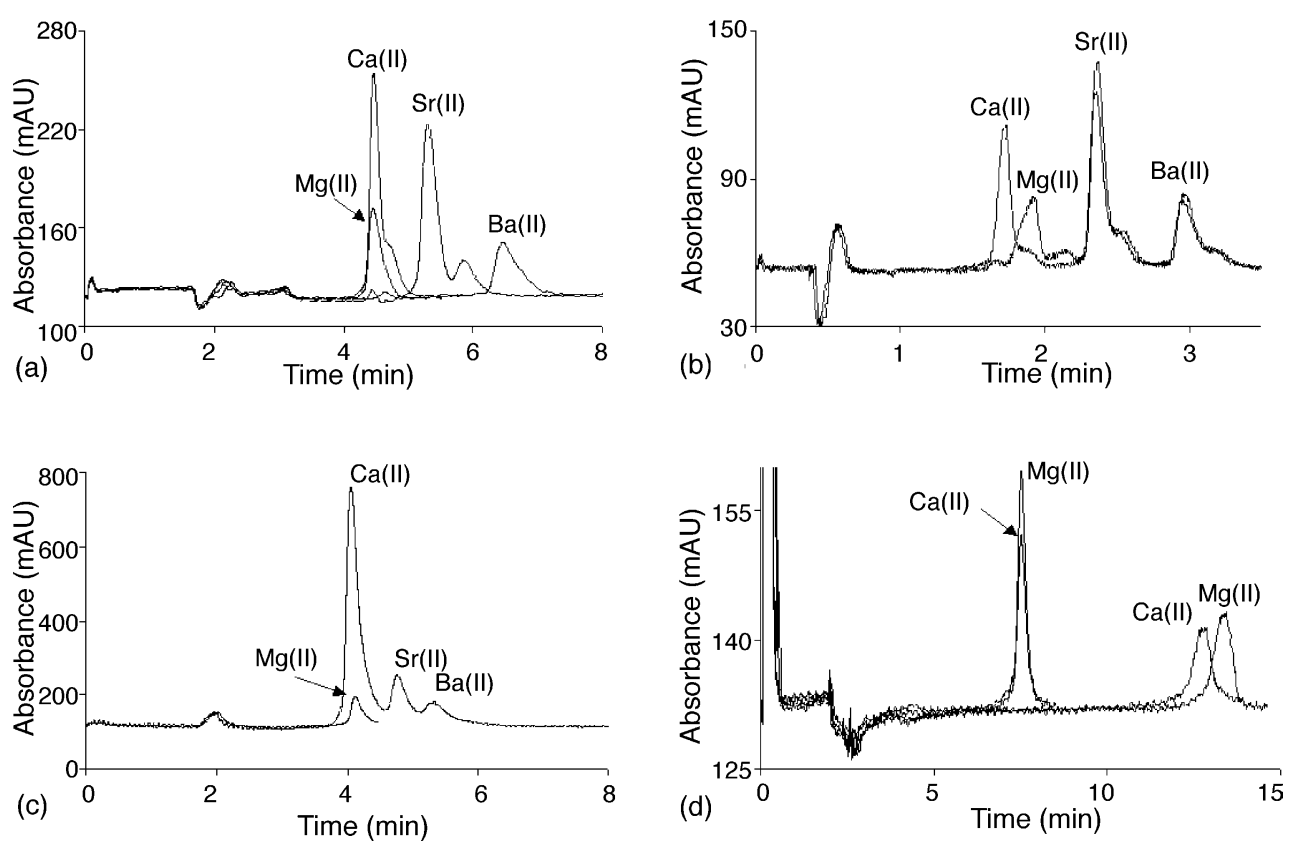

Fig. 1. Separations of alkaline earth metals on a bare silica monolith. Overlaid chromatograms of mixed alkaline earth standards obtained using a mobile phase of: (a) $70 \% \mathrm{MeCN}$ containing $31.3 \mathrm{mM}$ ammonium acetate $(\mathrm{pH} 4.6$ ), flow rate $=1 \mathrm{~mL} / \mathrm{min}$; (b) $70 \% \mathrm{MeCN}$ containing $23.4 \mathrm{mM}$ ammonium acetate (pH 5.55), flow rate $=4 \mathrm{~mL} / \mathrm{min}$; (c) $70 \% \mathrm{MeCN}$ containing $31.3 \mathrm{mM}$ sodium acetate $(\mathrm{pH} 4.6$ ), flow rate $=1 \mathrm{~mL} / \mathrm{min}$; (d) $80 \% \mathrm{MeCN}$ containing $41.2 \mathrm{mM}$ ammonium acetate at $\mathrm{pH} 4.9$ (retention of $\mathrm{Ca}(\mathrm{II})$ and $\mathrm{Mg}(\mathrm{II})=7.5 \mathrm{~min}$ ) and $\mathrm{pH} 5.9$ (retention of $\mathrm{Ca}(\mathrm{II})=12.7 \mathrm{~min}, \mathrm{Mg}(\mathrm{II})=13.5 \mathrm{~min}$ ), flow rate $=1 \mathrm{~mL} / \mathrm{min}$.

mobile phase conditions was unexpected, particularly when compared to previous studies on silica gel columns [20,21], although in most previous studies complexing eluents have been used which obviously affect the observed selectivity.

\section{2. $p H$ effects}

Using a $70 \% \mathrm{MeCN}$ mobile phase with an ammonium acetate buffer concentration of $23.4 \mathrm{mM}$, the effect upon retention of varying mobile phase $\mathrm{pH}$ from 4.6 to $5.55(n=3)$ was investigated. The results are included in Table 2. As expected, over this $\mathrm{pH}$ range retention times for all four cations increased and it was observed that at the higher $\mathrm{pH}$ values the partial separation of $\mathrm{Ca}(\mathrm{II})$ and $\mathrm{Mg}(\mathrm{II})$ was

Table 2

$\mathrm{pH}$ effect upon retention for alkaline earth metal ions on bare silica monolithic column using an acetonitrile mobile phase containing ammonium acetate buffer

\begin{tabular}{|c|c|c|c|c|}
\hline \multirow[t]{2}{*}{$\mathrm{pH}$} & \multicolumn{4}{|c|}{ Retention factor $(k)$} \\
\hline & $\operatorname{Mg}(\mathrm{II})$ & $\mathrm{Ca}(\mathrm{II})$ & $\operatorname{Sr}(\mathrm{II})$ & $\mathrm{Ba}(\mathrm{II})$ \\
\hline \multicolumn{5}{|c|}{$70 \% \mathrm{MeCN}, 23.4 \mathrm{mM}$ buffer } \\
\hline 4.60 & 1.79 & 1.97 & 2.26 & 3.01 \\
\hline 5.01 & 2.27 & 2.22 & 2.87 & 4.22 \\
\hline 5.55 & 3.37 & 2.60 & 3.37 & 4.72 \\
\hline \multicolumn{5}{|c|}{$80 \% \mathrm{MeCN}, 41.2 \mathrm{mM}$ buffer } \\
\hline 4.40 & 3.40 & 3.45 & & \\
\hline 4.90 & 3.38 & 3.38 & & \\
\hline 5.44 & 5.96 & 4.66 & & \\
\hline 5.94 & 6.82 & 6.47 & & \\
\hline
\end{tabular}

Flow rate $=1 \mathrm{~mL} / \mathrm{min}$ and column temperature $=20^{\circ} \mathrm{C}$. now possible, although the peak shape for $\mathrm{Mg}$ (II) was poor (Fig. 1(b) shows overlays of chromatograms from mixed standards obtained with a $70 \%$ meCN mobile phase containing $23.4 \mathrm{mM}$ buffer at $\mathrm{pH} 5.55$, run under an elevated flow rate of $4 \mathrm{~mL} / \mathrm{min}$ ). A small degree of peak splitting was now noted for all four peaks. In an attempt to eliminate this unusual peak splitting, increased buffer concentrations were investigated. Using an $80 \% \mathrm{MeCN}$ mobile phase, the overall buffer concentration was increased to $41.2 \mathrm{mM}$ (pH 4.9). Under these conditions the peak splitting evident at lower buffer concentrations was no longer apparent, although under these conditions $\mathrm{Ca}(\mathrm{II})$ and $\mathrm{Mg}(\mathrm{II})$ co-eluted once again.

Keeping these mobile phase \% $\mathrm{MeCN}$ and buffer concentrations constant but increasing $\mathrm{pH}$ up to 5.94, improved the separation whilst maintaining acceptable peak shapes and retention times (data included in Table 2). Fig. 1(d) shows overlaid chromatograms for standard solutions of $\mathrm{Mg}$ (II) and $\mathrm{Ca}(\mathrm{II})$ with the high buffer concentration adjusted to $\mathrm{pH} 4.9$ (peaks co-elute at $7.5 \mathrm{~min}$ ) and then $\mathrm{pH} 5.94$ (peaks eluting at $12.7 \mathrm{~min}-\mathrm{Ca}(\mathrm{II})$ and $13.5 \mathrm{~min}-\mathrm{Mg}(\mathrm{II})$ ). As can be seen from Fig. 1(d) peak shapes are no longer split at higher buffer concentrations, even at increased retention times, although obviously the column selectivity for $\mathrm{Ca}(\mathrm{II})$ and $\mathrm{Mg}(\mathrm{II})$ is still very similar.

\subsection{Alternative buffer}

The ammonium acetate in the acetonitrile mobile phase was replaced by sodium acetate buffer ( $\mathrm{pH} 4.6)$ and the effect of using an alternative buffer on alkaline earth selectivity was 
investigated. Peak splitting was once again observed at low buffer concentrations, however, increasing the sodium acetate buffer concentration to $62.5 \mathrm{mM}(70 \% \mathrm{MeCN})$ eliminated the problem of peak splitting whilst still allowing a separation of $\mathrm{Ca}(\mathrm{II}), \mathrm{Sr}(\mathrm{II})$ and $\mathrm{Ba}(\mathrm{II})$. There was no difference in the alkaline earth metal selectivity observed with the sodium acetate buffer, i.e., $\mathrm{Mg}$ (II) and $\mathrm{Ca}(\mathrm{II})$ were still observed to co-elute over the range of buffer concentrations studied (data included with transition metal data in Table 4) and the retention factors for the alkaline earth metal ions were similar to those obtained with the ammonium acetate buffer.

\subsection{Transition metals-organic solvent and buffer effects}

A number of studies have been carried out on the ionexchange capacities of various forms of silica gel for divalent cations, including transition and heavy metal ions [25-32]. In many cases, these investigations have studied relatively large particle size silica gels, and have not investigated high-performance phases for ion chromatographic separations. However, a number of studies have emerged using unmodified silica gels for ion chromatographic separations $[14,15,17-20]$, in some cases including selected transition metal ions $[16,25]$. In these studies, the retention, selectivity and efficiency exhibited, have been shown to be heavily influenced by the nature of the silica gel, including properties like metal content of the silica itself, and relative acidity of the silica surface.

Here, selectivity of the silica monolith for $\mathrm{Cu}(\mathrm{II}), \mathrm{Fe}(\mathrm{II})$, $\mathrm{Cd}(\mathrm{II}), \mathrm{Ni}(\mathrm{II}), \mathrm{Co}(\mathrm{II}), \mathrm{Mn}$ (II), $\mathrm{Zn}$ (II) and $\mathrm{Pb}$ (II) was investigated in $\mathrm{MeCN}$ based mobile phases, ranging again from 60 to $80 \% \mathrm{MeCN}$, buffered once more with varying concentrations of ammonium acetate-acetic acid ( $\mathrm{pH}$ 4.6). To reduce potential column contamination from $\mathrm{Fe}(\mathrm{III}), 1 \mathrm{mM}$ ascorbic acid was also added to all mobile phases used to reduce $\mathrm{Fe}(\mathrm{III})$ to $\mathrm{Fe}(\mathrm{II})$. However, under the mobile phase and detections conditions used, the response for $\mathrm{Fe}$ (II) was very poor, eluting as only a small peak between $\mathrm{Cu}$ (II) and $\mathrm{Cd}(\mathrm{II})$. As with the alkaline earth metal ions, significant retention of each of the above metals was noted, with the retention order being $\mathrm{Cu}$ (II) $<\mathrm{Fe}$ (II) $<\mathrm{Cd}$ (II) $<\mathrm{Ni}$ (II) $<\mathrm{Co}$ (II) $<\mathrm{Mn}$ (II) $<$ $\mathrm{Pb}(\mathrm{II})<\mathrm{Zn}$ (II).

Interestingly, this retention order is quite different from those reported by others on bare silica gel columns. According to Iler [32], the adsorption of transition metal ions on silica is due to interaction with active sites at the silica surface which act like ligands, and the specificity of adsorption is therefore related to the tendency of the metal atom to form covalent bonds. Schindler et al. [31] supports this theory having found that the ligand properties of surface silanol groups for transition metal ions (Fe(III), $\mathrm{Cu}$ (II), $\mathrm{Cd}(\mathrm{II})$ and $\mathrm{Pb}(\mathrm{II})$ ) strongly correlate with known stability constants for corresponding metal-hydroxocomplexes. In fact, this stability data are in good agreement with selectivity reported in several papers [28,30,31], where the fol- lowing order of specificity of formation of covalent bonds with silica surface was observed for transition metals: $\mathrm{Cd}$ (II) $<\mathrm{Ni}$ (II) $<\mathrm{Zn}$ (II) $<\mathrm{Co}$ (II) $<\mathrm{Cu}$ (II) $<\mathrm{Pb}$ (II) .

The use of bare silica particle columns for separation of $\mathrm{Cu}(\mathrm{II}), \mathrm{Cd}(\mathrm{II}), \mathrm{Pb}$ (II) and $\mathrm{Tl}(\mathrm{I})$ ions was also reported by Janos et al. [25], who used sodium acetate, sodium tartrate and sodium hydroxybutyrate aqueous solutions of different $\mathrm{pH}$ and concentration. The authors found that selectivity of separation depends strongly on secondary complexation equilibria with organic acids from the eluents. Here, with the monolithic silica column, the mobile phase contained ammonium acetate and so both ammonium and acetate could affect observed selectivity through complexation. The most obvious deviations from the above data were firstly the retention of $\mathrm{Cu}(\mathrm{II})$, which was relatively low under all mobile phase conditions and was least affected by increasing the concentration of MeCN. Secondly, was the fact that $\mathrm{Zn}$ (II) was strongly retained under all conditions, only eluting under conditions of low MeCN (60\%) and high buffer concentration. Even under such conditions, Zn(II) eluted as an excessively broad and tailed peak. This unusual selectivity and poor peak shapes for $\mathrm{Zn}(\mathrm{II})$, on similar silica monolithic columns (Merck Performance-Si) has been specifically noted in two previous studies, one where the silica monolith was modified with iminodiacetic acid [11,12], the second where the silica monolith was modified with 2,6-diaminohexanoic acid [33]. Obviously, the results here would indicate that the effects reported in the above two studies originate from the monolith backbone itself, rather than the attached functionalities. The unusual behaviour of $\mathrm{Cu}$ (II) could be due to the formation of $\mathrm{Cu}(\mathrm{II})-\mathrm{MeCN}$ complexes, leading to reduced retention. This is supported by data [34], which prove a specific solvation of $\mathrm{Cu}$ (II) ions by $\mathrm{MeCN}$ molecules.

Table 3 shows the retention data as a function of $\% \mathrm{MeCN}$ and buffer concentration, obtained from investigating 15 different mobile phase conditions. Clearly, as with alkaline earth metal ions, retention of transition metal ions can be drastically increased using high concentrations of $\mathrm{MeCN}$ within the mobile phase. In addition, the selectivity shown for each cation was sufficient to result in a number of possible separations. Overlaid chromatograms of individual standards are shown in Fig. 2, with Fig. 2(a) showing retention with a 70\% $\mathrm{MeCN}$ mobile phase containing $15.6 \mathrm{mM}$ ammonium acetate buffer (pH 4.6). Fig. 2(b) shows the retention of the same standards $(\mathrm{Pb}$ (II) and $\mathrm{Zn}$ (II) retained completely) with an $80 \% \mathrm{MeCN}$ mobile phase, containing a $5.2 \mathrm{mM}$ ammonium acetate buffer ( $\mathrm{pH} 4.6$ ), and although the chromatograms show some evidence of either peak fronting or tailing, baseline resolution of the cations was easily achieved.

\subsection{Alternative solvents}

Clearly, the above results suggested the nature of the organic solvent may have been an important factor in the observed selectivity. To investigate this further a brief study was undertaken using $\mathrm{MeOH}$ in place of $\mathrm{MeCN}$. $\mathrm{MeOH}$ 
Table 3

Retention data for transition metal ions on a $10 \mathrm{~cm}$ bare silica monolithic column with $\mathrm{MeCN}$ or $\mathrm{MeOH}$ based mobile phases containing varying amounts of ammonium acetate buffer- $-(\mathrm{pH} 4.6)$

\begin{tabular}{|c|c|c|c|c|c|c|}
\hline \multirow[t]{2}{*}{$\log [E]$} & \multicolumn{6}{|l|}{$\log k$} \\
\hline & $\mathrm{Cu}(\mathrm{II})$ & $\mathrm{Cd}(\mathrm{II})$ & $\mathrm{Ni}(\mathrm{II})$ & $\mathrm{Co}(\mathrm{II})$ & $\mathrm{Mn}(\mathrm{II})$ & $\mathrm{Pb}(\mathrm{II})$ \\
\hline \multicolumn{7}{|c|}{$60 \% \mathrm{MeCN}$} \\
\hline-2.38 & -0.12 & 0.53 & 0.56 & 0.58 & 0.62 & 0.84 \\
\hline-1.98 & -0.35 & 0.04 & 0.19 & 0.22 & 0.24 & 0.59 \\
\hline-1.68 & -0.52 & -0.30 & -0.13 & -0.10 & -0.07 & 0.22 \\
\hline-1.50 & -0.60 & -0.53 & -0.30 & -0.26 & -0.26 & 0.00 \\
\hline Slope & -0.551 & -1.188 & -0.988 & -0.964 & -1.00 & -0.967 \\
\hline$R^{2}$ & 0.999 & 0.999 & 0.999 & 0.999 & 0.999 & 0.971 \\
\hline \multicolumn{7}{|c|}{$60 \% \mathrm{MeOH}$} \\
\hline-1.68 & -1.50 & -0.67 & & & -0.56 & -0.28 \\
\hline \multicolumn{7}{|c|}{$70 \% \mathrm{MeCN}$} \\
\hline-2.51 & 0.06 & 0.78 & 0.83 & 0.86 & 0.93 & \\
\hline-2.11 & -0.26 & 0.28 & 0.48 & 0.55 & 0.59 & 1.09 \\
\hline-1.81 & -0.40 & -0.02 & 0.24 & 0.33 & 0.37 & 0.78 \\
\hline-1.63 & -0.52 & -0.26 & 0.02 & 0.09 & 0.11 & 0.50 \\
\hline Slope & -0.650 & -1.162 & -0.904 & -0.852 & -0.906 & -1.213 \\
\hline$R^{2}$ & 0.987 & 0.998 & 0.995 & 0.986 & 0.985 & 0.986 \\
\hline \multicolumn{7}{|c|}{$70 \% \mathrm{MeOH}$} \\
\hline-1.81 & -0.21 & -0.53 & & & -0.40 & 0.06 \\
\hline \multicolumn{7}{|c|}{$80 \% \mathrm{MeCN}$} \\
\hline-2.68 & 0.16 & 1.23 & & 1.36 & 1.51 & \\
\hline-2.28 & 0.02 & 0.85 & 0.98 & 1.11 & 1.24 & \\
\hline-1.99 & -1.16 & 0.46 & 0.67 & 0.81 & 0.88 & 1.33 \\
\hline-1.80 & -0.22 & 0.31 & 0.57 & 0.71 & 0.74 & 1.19 \\
\hline-1.69 & -0.25 & 0.20 & 0.47 & 0.59 & 0.63 & 1.10 \\
\hline Slope & -0.443 & -1.057 & -0.849 & -0.786 & -0.912 & -1.087 \\
\hline$R^{2}$ & 0.990 & 0.995 & 0.982 & 0.992 & 0.990 & 0.967 \\
\hline \multicolumn{7}{|c|}{$80 \% \mathrm{MeOH}$} \\
\hline-1.99 & 0.19 & -0.37 & -0.32 & -0.28 & -0.15 & 0.54 \\
\hline \multicolumn{7}{|c|}{$90 \% \mathrm{MeOH}$} \\
\hline-2.29 & 0.89 & -0.03 & -0.005 & 0.11 & 0.32 & \\
\hline
\end{tabular}

Flow rate $=1 \mathrm{~mL} / \mathrm{min}$, column temperature $=20^{\circ} \mathrm{C}$ and post-column reaction detection with PAR monitored at $510 \mathrm{~nm}$.

is known to form strong hydrogen bonds with the surface silanol groups and so it was expected that relative retention should be less in this case. In addition, the solvation of metal ions with $\mathrm{MeOH}$ molecules is different as compared with $\mathrm{MeCN}$, and so this should also alter the observed selectivity. Mobile phases containing 60-90\% $\mathrm{MeOH}$ were investigated, each containing varying amounts of ammonium-acetate buffer. The resultant retention data have been included in Table 3 for comparison with $\mathrm{MeCN}$ data. As can be seen from the tabulated data, under similar buffer concentration, retention times were generally significantly lower with the $\mathrm{MeOH}$ based mobile phases compared with MeCN. Exceptions to this observation were the retention of $\mathrm{Zn}$ (II), which was once more selectively retained, and the behaviour of $\mathrm{Cu}(\mathrm{II})$, which showed a rapid increase in retention under high $\mathrm{MeOH}$ concentrations, such that at 80 and $90 \% \mathrm{MeOH}$ the retention order was now found to be $\mathrm{Cd}$ (II) $<\mathrm{Ni}$ (II) $<\mathrm{Co}$ (II) $<\mathrm{Mn}$ (II) $\ll \mathrm{Cu}$ (II). These observations support the above assumption that selective $\mathrm{Cu}(\mathrm{II})-\mathrm{MeCN}$ interactions are primarily responsible for the relatively low retention of $\mathrm{Cu}$ (II) with $\mathrm{MeCN}$ based mobile phases.

Peak shapes for transition/heavy metal ions with the $\mathrm{MeOH}$ mobile phases were generally acceptable, with no signs of the peak splitting seen with the alkaline earth metal ions. Overall selectivity was also sufficient to achieve several useful separations of important metals. Fig. 3 shows some overlaid standard chromatograms, achieved using an (a) $60 \% \mathrm{MeOH}, 21.1 \mathrm{mM}$ ammonium acetate buffer mobile phase ( $\mathrm{pH} 4.7$ ), (b) $80 \% \mathrm{MeOH}, 15.6 \mathrm{mM}$ ammonium acetate buffer mobile phase (pH 4.7) and (c) a 90\% MeOH, 5.1 mM ammonium acetate buffer mobile phase ( $\mathrm{pH} 4.7)$.

\subsection{Alternative buffers}

Using the $80 \%$ acetonitrile mobile phase, the use of a sodium acetate buffer concentration over the range 10.3-41.2 mM ( $\mathrm{pH} 4.6)$ was investigated and the effect on transition metal ion retention is shown in Table 4 . The retention of all the transition ions studied increased significantly when the sodium acetate buffer was employed. This difference in retention can be attributed to complex formation, which may occur with the ammonium in the $\mathrm{MeCN} / \mathrm{ammonium}$ acetate buffer mobile phase, and hence, when the ammonium acetate was replaced with sodium acetate, an increase in transition metal ion retention at 60 ,

Table 4

Retention data for alkaline earth and transition metal ions on a $10 \mathrm{~cm}$ bare silica monolithic column with $\mathrm{MeCN}$ based mobile phases containing varying amounts of sodium acetate buffer- $(\mathrm{pH} 4.6)$

\begin{tabular}{|c|c|c|c|c|c|c|}
\hline \multirow[t]{2}{*}{$\log [E]$} & \multicolumn{6}{|c|}{$\log k^{\prime}$} \\
\hline & \multicolumn{2}{|c|}{$\mathrm{Ca}(\mathrm{II})$} & $\operatorname{Mg}(\mathrm{II})$ & \multicolumn{2}{|c|}{$\mathrm{Sr}(\mathrm{II})$} & $\mathrm{Ba}(\mathrm{II})$ \\
\hline \multicolumn{7}{|c|}{$70 \% \mathrm{MeCN}$} \\
\hline-211 & \multicolumn{2}{|c|}{0.68} & 0.68 & \multicolumn{2}{|c|}{0.83} & 0.96 \\
\hline-1.81 & \multicolumn{2}{|c|}{0.40} & 0.41 & \multicolumn{2}{|c|}{0.54} & 0.65 \\
\hline-1.63 & \multicolumn{2}{|c|}{0.16} & 0.16 & \multicolumn{2}{|c|}{0.29} & 0.39 \\
\hline-1.51 & \multicolumn{2}{|c|}{0.12} & 0.12 & \multicolumn{2}{|c|}{0.27} & 0.36 \\
\hline Slope & \multicolumn{2}{|c|}{-0.986} & -0.988 & \multicolumn{2}{|c|}{-0.985} & -1.046 \\
\hline \multirow[t]{2}{*}{$R^{2}$} & \multicolumn{2}{|c|}{0.980} & 0.979 & \multicolumn{2}{|c|}{0.969} & 0.973 \\
\hline & $\mathrm{Cu}(\mathrm{II})$ & $\mathrm{Cd}(\mathrm{II})$ & $\mathrm{Ni}(\mathrm{II})$ & $\mathrm{Co}(\mathrm{II})$ & $\operatorname{Mn}(\mathrm{II})$ & $\mathrm{Pb}(\mathrm{II})$ \\
\hline \multicolumn{7}{|c|}{$60 \% \mathrm{MeCN}$} \\
\hline-1.80 & 0.41 & -0.09 & 0.06 & 0.13 & 0.16 & 0.61 \\
\hline \multicolumn{7}{|c|}{$70 \% \mathrm{MeCN}$} \\
\hline-1.80 & 0.66 & 0.11 & 0.26 & 0.38 & 0.42 & 0.95 \\
\hline \multicolumn{7}{|c|}{$80 \% \mathrm{MeCN}$} \\
\hline-1.99 & - & 0.56 & 0.80 & 1.07 & 1.20 & - \\
\hline-1.80 & 0.98 & 0.38 & 0.62 & 0.82 & 0.88 & 1.31 \\
\hline-1.69 & 0.82 & 0.27 & 0.52 & 0.71 & 0.76 & 1.11 \\
\hline-1.39 & 0.47 & 0.16 & 0.37 & 0.50 & 0.53 & 0.72 \\
\hline Slope & -1.211 & -0.691 & -0.701 & -0.937 & -1.080 & -1.392 \\
\hline$R^{2}$ & 0.996 & 0.915 & 0.969 & 0.971 & 0.960 & 0.994 \\
\hline
\end{tabular}

Flow rate $=1 \mathrm{~mL} / \mathrm{min}$ and column temperature $=20^{\circ} \mathrm{C}$. 

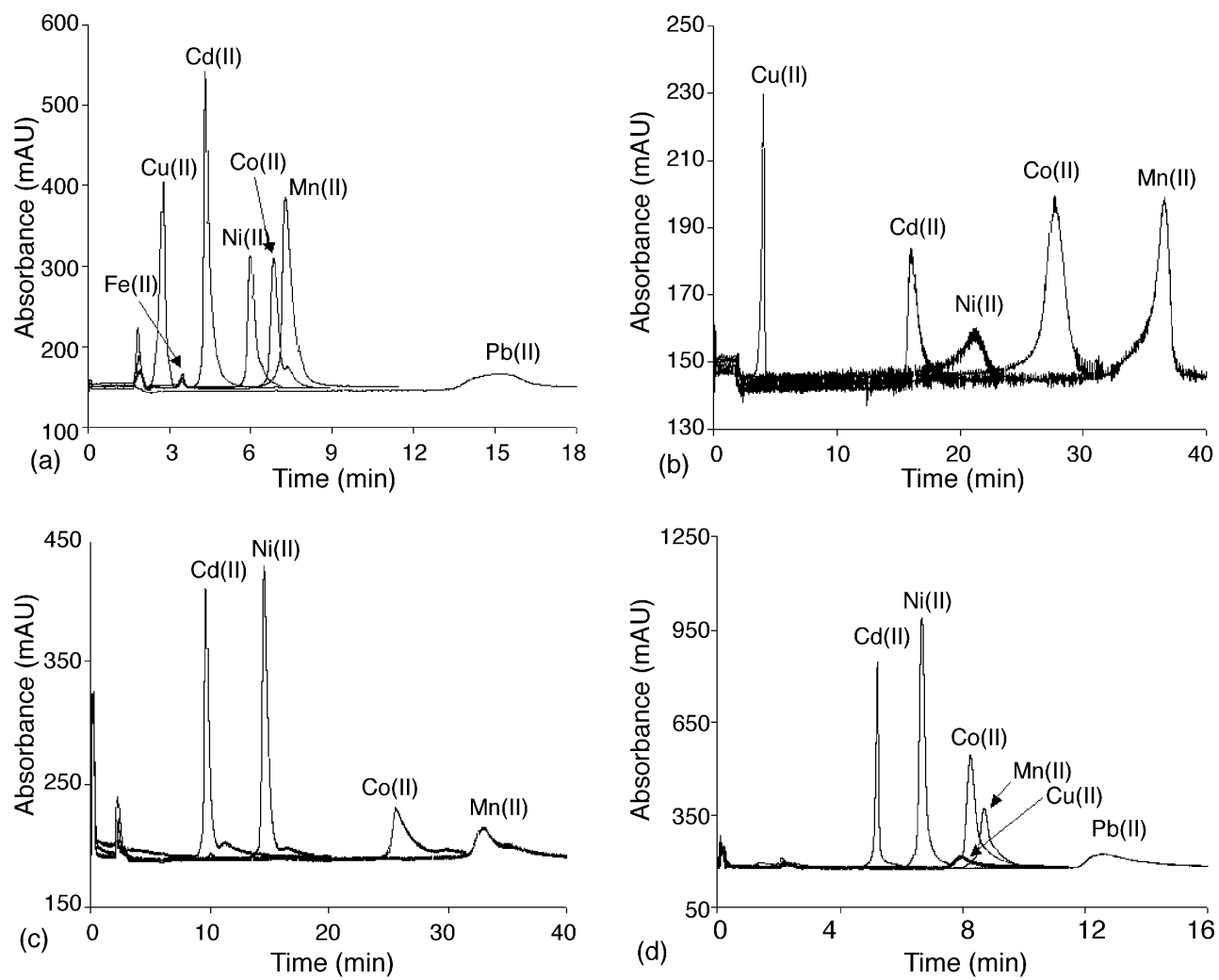

Fig. 2. Overlaid standard chromatograms of transition and heavy metal ions on a bare silica monolith using a mobile phase of: (a) $70 \%$ MeCN containing $15.6 \mathrm{mM}$ ammonium acetate at $\mathrm{pH} 4.6$; (b) $80 \% \mathrm{MeCN}$ containing $5.2 \mathrm{mM}$ ammonium acetate at $\mathrm{pH} 4.6$; (c) $80 \%$ MeCN containing $10.3 \mathrm{mM}$ sodium acetate buffer at $\mathrm{pH} 4.6$; (d) $80 \% \mathrm{MeCN}$ containing $41.2 \mathrm{mM}$ sodium acetate buffer at $\mathrm{pH} 4.6$, flow rate $=1 \mathrm{~mL} / \mathrm{min}$.

70 and $80 \%$ was observed. In particular, the behaviour of $\mathrm{Cu}(\mathrm{II})$ was interesting, considering the small retention of $\mathrm{Cu}$ (II) observed to be using the ammonium acetate buffer. In contrast, with the sodium acetate buffer, the retention of $\mathrm{Cu}(\mathrm{II})$ was significant and affected strongly by increasing the buffer concentration, i.e., at $15.5 \mathrm{mM}$ sodium acetate buffer concentration, $\mathrm{Cu}$ (II) eluted almost 4 min after $\mathrm{Mn}$ (II), however, at $41.2 \mathrm{mM}, \mathrm{Cu}(\mathrm{II})$ was observed to elute before both $\mathrm{Co}$ (II) and $\mathrm{Mn}$ (II). Therefore, an increase in the sodium acetate buffer concentration from 10.3 to $41.2 \mathrm{mM}$ resulted in a change in retention order from $\mathrm{Cd}$ (II) $<\mathrm{Ni}$ (II) $<$ $\mathrm{Co}$ (II) $<\mathrm{Mn}$ (II) $\ll \mathrm{Cu}$ (II) $\ll \mathrm{Pb}$ (II) to $\mathrm{Cd}$ (II) $<\mathrm{Ni}$ (II) $<\mathrm{Cu}$ (II) $<\mathrm{Co}$ (II) $<\mathrm{Mn}$ (II) $<\mathrm{Pb}$ (II), as shown in Fig. 2(c and d). It is clear from this study and the previously results preformed using $\mathrm{MeOH}$ in place of acetonitrile in the mobile phase, that the retention of $\mathrm{Cu}$ (II) is affected by both the formation of $\mathrm{Cu}(\mathrm{II})-\mathrm{MeCN}$ complexes and complexation with ammonium in the mobile phase.

With the sodium acetate based mobile phase the optimum eluent conditions for the separation of the $\mathrm{Cd}(\mathrm{II}), \mathrm{Ni}(\mathrm{II})$, $\mathrm{Co}(\mathrm{II})$ and $\mathrm{Mn}$ (II) were found to be $80 \%$ acetonitrile containing $10.3 \mathrm{mM}$ sodium acetate buffer ( $\mathrm{pH} 4.6$ ) (as in Fig. 2(c)). However, the run time required for the separation of these four analytes was greater than $35 \mathrm{~min}$ and as a result, excessive retention of $\mathrm{Cu}$ (II) and especially $\mathrm{Pb}$ (II) was observed, whilst using $80 \%$ acetonitrile/10.3 $\mathrm{mM}$ ammonium acetate buffer, the separation of $\mathrm{Cu}(\mathrm{II}), \mathrm{Cd}(\mathrm{II}), \mathrm{Ni}(\mathrm{II}), \mathrm{Co}(\mathrm{II})$ and $\mathrm{Mn}$ (II) was possible in $<20 \mathrm{~min}$ at $1 \mathrm{~mL} / \mathrm{min}$.

Using the sodium acetate buffer (as with the ammonium based mobile phase) there was still evidence of peak splitting for certain transition metal ions, especially at low buffer concentrations. For most cations this splitting was eliminated when using higher buffer concentrations, although was still present to a minor degree in some cases. Matching of the sample matrix with the mobile phase did affect the observed splitting effect to some degree but in an unpredictable manor, and is the subject of further investigation. In addition, the comparison of new and old silica monolithic columns was carried out to eliminate the possibility of column degradation being the reason for the observed splitting, and this comparison showed the effects to be reproducible between used and new columns.

\section{7. $p H$ effects}

As with alkaline earth metals, it was found that the retention times of transition metal cations also varied considerably with mobile phase $\mathrm{pH}$. Increasing mobile phase $\mathrm{pH}$ resulted in rapid increases in retention, such that when using an $80 \%$ $\mathrm{MeCN}$ mobile phase containing $10.3 \mathrm{mM}$ of the ammonium acetate buffer at $\mathrm{pH} 5.6$, the retention of $\mathrm{Ni}(\mathrm{II})$ was $>1 \mathrm{~h}$, and $\mathrm{Co}(\mathrm{II}), \mathrm{Mn}(\mathrm{II}), \mathrm{Pb}$ (II) and $\mathrm{Zn}$ (II) were all completely retained. 

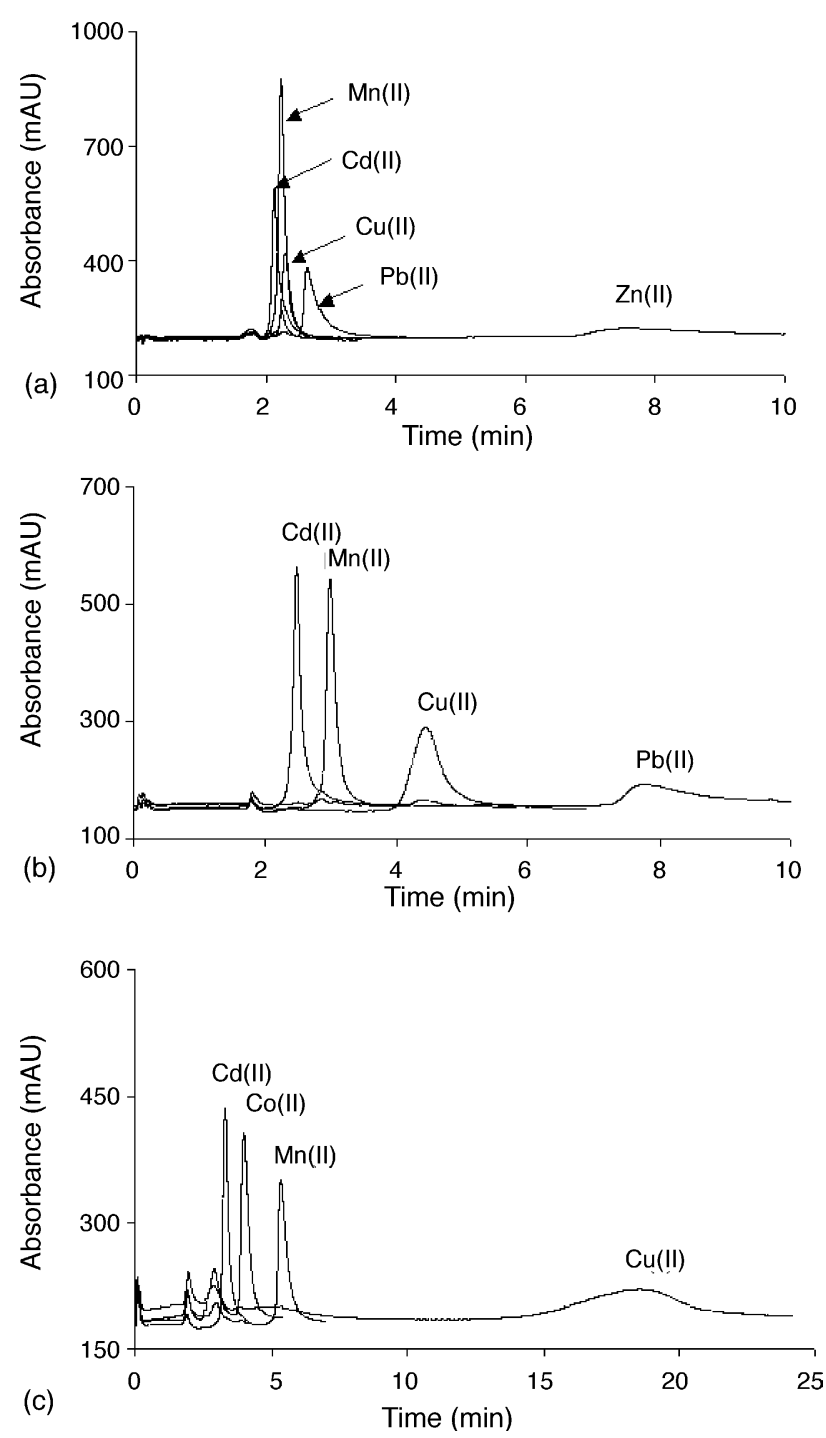

Fig. 3. Overlaid standard chromatograms of transition and heavy metal ions on a bare silica monolith using a mobile phase of: (a) $60 \% \mathrm{MeOH}$ containing $21.1 \mathrm{mM}$ ammonium acetate at $\mathrm{pH} 4.7$; (b) $80 \% \mathrm{MeOH}$ containing $10.3 \mathrm{mM}$ ammonium acetate at $\mathrm{pH} 4.7$; (c) $90 \% \mathrm{MeOH}$ containing $5.1 \mathrm{mM}$ ammonium acetate at $\mathrm{pH} 4.7$, flow rate $=1 \mathrm{~mL} / \mathrm{min}$.

Alternatively, it was noted that reducing $\mathrm{pH}$ resulted in a considerable reductions in retention, resulting in the virtual co-elution of $\mathrm{Cd}(\mathrm{II}), \mathrm{Ni}$ (II), $\mathrm{Co}$ (II) and $\mathrm{Mn}$ (II) when using the $80 \% \mathrm{MeCN}$ mobile phase at $\mathrm{pH} 3.5$, with all metal ions eluting between 3.7 and $3.8 \mathrm{~min}$. Therefore, a study of $\mathrm{pH}$ effects from $\mathrm{pH} 3.5$ to $5.6(n=5)$ using the $80 \% \mathrm{MeCN}$ mobile phase was carried out and in general it was found that both retention and resolution improved with increasing mobile phase $\mathrm{pH}$. These retention data are shown graphically as Fig. 4. The graph shows most cations behave similarly, with the exception of $\mathrm{Cu}(\mathrm{II})$, which showed decreased retention at higher $\mathrm{pH}$. Here, the explanation is thought to lie in the formation of ammino complexes with ammonium ions within the buffer under high $\mathrm{pH}$ conditions.

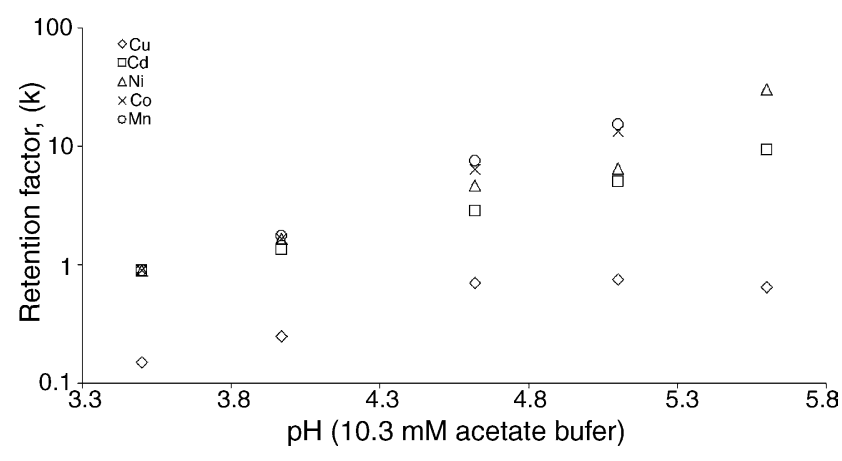

Fig. 4. Effect of mobile phase $\mathrm{pH}$ upon retention of transition metals on bare silica monolith using a mobile phase of $80 \% \mathrm{MeCN}$ containing $10.3 \mathrm{mM}$ ammonium acetate buffer, flow rate $=1 \mathrm{~mL} / \mathrm{min}$ (at pH 5.6, Co(II) and $\mathrm{Mn}$ (II) were completely retained).

\subsection{Flow rate effects}

Obviously, a great deal of interest in monolithic columns for chromatographic purposes has been due to the potential for rapid separations. Here, using a mobile phase composition of $80 \% \mathrm{MeCN}$ with $10.3 \mathrm{mM}$ ammonium acetate ( $\mathrm{pH} 4.6$ ), the mobile phase flow rates were systematically increased from 1 to $5 \mathrm{~mL} / \mathrm{min}$. Optimal flow rate, in terms of measured peak efficiencies was found to be between 0.15 and $0.2 \mathrm{~cm} / \mathrm{s}$ for most metals (corresponding to between $\sim 1.5$ and $2.0 \mathrm{~mL} / \mathrm{min}$ ). At a flow rate velocity of $0.2 \mathrm{~cm} / \mathrm{s}$, the average efficiency (HETP) for the five metals shown was found to be $40 \mu \mathrm{m}$, ranging from 25.9 to $57.8 \mu \mathrm{m}$, equivalent to an average efficiency of $\sim 25,000 \mathrm{~N} / \mathrm{m}$ (efficiency values calculated using peak widths measured at half height).

Fig. 5 shows cation separations run at flow rates of $1 \mathrm{~mL} / \mathrm{min}, 3 \mathrm{~mL} / \mathrm{min}$ and $5 \mathrm{~mL} / \mathrm{min}$, using the mobile phase conditions used for the flow rate study described above. Resolution of the five transition metal cations shown was clearly very acceptable, with possibilities to improve the separation further through the use of complexing eluents or gradient separations. With the use of the elevated mobile phase flow rate, which could be increased to $>5 \mathrm{~mL} / \mathrm{min}$ without excessive backpressure if required, transition metal separations can be

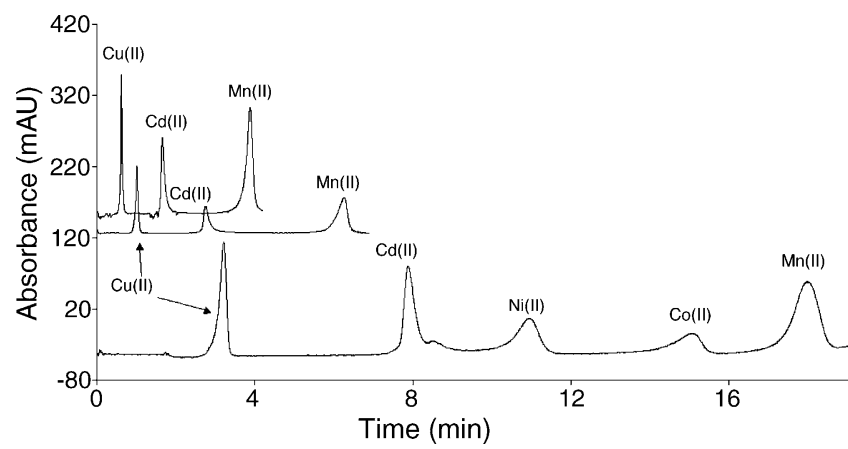

Fig. 5. Separations of selected transition metal ions on a bare silica monolith using a mobile phase of $80 \% \mathrm{MeCN}$ containing $10.3 \mathrm{mM}$ ammonium acetate buffer at $\mathrm{pH} 4.6$ at flow rates of $1 \mathrm{~mL} / \mathrm{min}, 3 \mathrm{~mL} / \mathrm{min}$ and $5 \mathrm{~mL} / \mathrm{min}$. 
achieved in as little as 2-3 min, with acceptable resolution and peak shapes, as illustrated by Fig. 5 .

\section{Conclusions}

This study shows that bare silica monoliths can be used for efficient and practical separations of alkaline earth and transition metal cations, without surface modification, through the use of organic based mobile phases, in what can be best described as solvent enhanced ion chromatography. The organic nature of the mobile phase enhances the electrostatic interaction of the analyte ions and the fixed ion-exchange site, in this case the dissociated silanol groups, through reducing the associated number of waters of hydration. However, this effect is dependent upon the nature of the organic solvent and significant selectivity changes can be obtained through correct choice of solvent. The assumption that the observed retention is simply enhanced ion exchange is verified by the effects of both $\mathrm{pH}$ and buffer type and concentration, which are as expected for a simple ion-exchange system. Finally, the unique selectivity of Chromolith bare silica monolithic columns for $\mathrm{Zn}$ (II) and is worthy of further investigation.

\section{Acknowledgements}

The authors would like to thank the referees of this work for their constructive comments and suggestions.

\section{References}

[1] H. Minakuchi, K. Nakanisihi, N. Soga, N. Ishizuka, N. Tanaka, Anal Chem. 68 (1996) 3498.

[2] F. Svec, J. Sep. Sci. 27 (2004) 747.

[3] D. Connolly, D. Victory, B. Paull, J. Sep. Sci. 27 (2004) 912.

[4] D. Victory, P. Nesterenko, B. Paull, Analyst 129 (2004) 700.

[5] P. Hatsis, C.A. Lucy, Analyst 127 (2002) 451

[6] P.N. Nesterenko, M.A. Rybalko, Mendeleev Commun. 14 (2004) 121.
[7] B. Paull, C. O'Riordain, P.N. Nesterenko, Chem. Commun. (2005) 215.

[8] J. Hutchinson, P. Zakaria, A.R. Bowie, M. Macka, N. Avdalovic, P.R. Haddad, Anal. Chem. 77 (2005) 407.

[9] P. Zakaria, J.P. Hutchinson, N. Avdalovic, Y. Liu, P.R. Haddad, Anal. Chem. 77 (2005) 417.

[10] Q. Xu, K. Tanaka, M. Mori, M.I. Helaleh, H. Toada, W. Hu, K. Hasebe, Chromatographia 57 (2003) 19.

[11] E. Sugrue, P. Nesterenko, B. Paull, J. Sep. Sci. 27 (2004) 921.

[12] E. Sugrue, P. Nesterenko, B. Paull, Analyst 128 (2003) 417.

[13] P.N. Nesterenko, B. Paull, Trends Anal. Chem. 24 (2005) 295.

[14] B.W. Pack, D.S. Risley, J. Chromatogr. A 1073 (2005) 269.

[15] K. Ohta, M. Sando, K. Tanaka, P. Haddad, J. Chromatogr. A 752 (1996) 167

[16] K. Ohta, K. Tanaka, B. Paull, P. Haddad, J. Chromatogr. A 770 (1997) 219.

[17] K. Ohta, K. Tanaka, Anal. Chim. Acta 381 (1999) 265.

[18] E. Munaf, R. Zein, T. Takeuchi, T. Miwa, Anal. Chim. Acta 334 (1996) 39

[19] E. Munaf, R. Zein, T. Takeuchi, T. Miwa, Anal. Chim. Acta 341 (1997) 225.

[20] R.L. Smith, D.J. Pietrzyk, Anal. Chem. 56 (1984) 610.

[21] Y. Takeda, K. Ishida, T. Hasegawa, A. Katoh, J. Chromatogr. A 1049 (2004) 233.

[22] G.J. Moody, J.D.R. Thomas, Analyst 93 (1968) 557.

[23] B. Paull, P.N. Nesterenko, Analyst 130 (2005) 134.

[24] A.I. Elefterov, M.G. Kolpachnikova, P.N. Nesterenko, O.A. Shpigun, J. Chromatogr. A 769 (1997) 179.

[25] P. Janos, K. Stulik, V. Pacakova, Talanta 38 (1991) 1445.

[26] D.L. Dugger, J.H. Stanton, B.L. McConnel, B.N. Irby, W.W. Cummings, R.W. Maatman, J. Phys. Chem. 68 (1964) 757.

[27] E. Akatsu, R. Ono, K. Tsukuechi, H. Uchiyama, J. Nucl. Sci. Technol. 2 (1965) 141.

[28] B.N. Laskorin, V.V. Strelko, D.N. Strahesko, V.I. Denisov, Silica Gel-Based Sorbents in Radiochemistry, Atomizdat, Moscow, 1977.

[29] G.C. Bye, M. McEvoy, M.A. Malati, J. Chem. Soc. Faraday Trans. 1 (79) (1983) 2311.

[30] H.H. Tran, F.A. Roddick, J.A. 'Donnel, Water Res. 33 (1999) 2992.

[31] P.W. Schindler, B. Fürst, R. Dick, P.U. Wolf, J. Colloid Interface Sci. 55 (1976) 469

[32] R.K. Iler, The Chemistry of Silica. Solubility, Polymerization, Colloid and Surface Properties and Biochemistry, A Wiley/Interscience Publication, New York/Chichester/Brisbane/Toronto/Singapore, 1979.

[33] E. Sugrue, P.N. Nesterenko, B. Paull, J. Chromatogr. A 1075 (2005) 167.

[34] V.N. Vandyshev, Russ. J. Gen. Chem. 73 (2003) 855. 